\title{
Articles
}

\section{Media and global conflict: An International Crisis Group case study}

ABSIRACI

The Pacific region is part of a larger world, far from being as isolated from centres of global power as a glance at the map might imply, but instead caught up in a web of multilateral relations with binding effects on its future progress and prosperity. This article considers such connections, in regard to both governmental and non-government agencies, referring in particular to the proliferation of highly influential non-governmental organisations in the region, as in the world at large. It treats the European Union handling of the December 2006 Fijian coup d'état and its aftermath as a case study in government-to-government relations, and it provides secondly a detailed case study on the operations of one outstanding example of a non-governmental organisation, the International Crisis Group.

\section{LEE DUFFIELD}

Queensland University of Technology

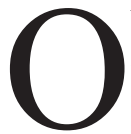

$\mathrm{N}$ the weekend of 14-15 April 2007, three ministers from the military-backed 'interim' government of Fiji travelled to Brussels to face questions and seek to obtain guarantees of continued, vital financial assistance for the nation's economy. The incident might have been seen as a case of colonial obeisance had it not been for the clearly contractual character of the European Union's Cotonou Agreement, under which development assistance to African, Caribbean and Pacific countries is tied to observance of agreed standards on human rights, governance and suppression of official corruption. It also made a point that the Pacific region is part of a larger world, far from being as isolated from centres of global power as a glance at 
the map might imply, but instead caught up in a web of multilateral relations with binding effects on its future progress and prosperity.

This article considers such connections, in regard to both governmental and non-government agencies, referring in particular to the proliferation of highly influential non-governmental organisations (NGOs) in the region, as in the world at large. It treats the European Union (EU) handling of the December 2006 Fijian coup d'état and its aftermath as a case study in government-togovernment relations, and it provides secondly a detailed case study on the operations of one outstanding example of a non-governmental organisation, the International Crisis Group (called 'Crisis Group').

It is reiterated in the article that most often government and non-government bodies in the field of economic and civic development are cosmopolitan and function on an international plane; they overlap in their structures and functions, collaborate and combine; ultimately agree on similar policy goals, and so work together as a common movement.

\section{Government agencies: The European Union}

In relations between Fiji and Europe this year, the EU position emphasised patient dialogue, and after talks it agreed to continued release of money for development purposes, as the Fijian authorities had undertaken to lift their Public Emergency Regulations in May 2007 and schedule free elections before 1 March 2009 (EC Pacific, 19 April 2007, 22 June 2007). This review of the process of consultation adopts the method of tracing the public record in media reportage and published announcements by the parties. It was enabled especially by the policy of openness insisted on by the EU in its standard operating procedures.

The gravity of the situation had been made apparent, in fact heavily publicised through the EU's insistence on transparency, providing an 'open book' on the fact of negotiations, the issues and demands, and amounts of money brought into the discussion. The initial fact of the ministerial mission to Europe in April was not kept secret in Suva, and once picked up by the Fiji Times (15 April 2007) the essential information from then on was given out as the process unfolded by the European Commission through its office in Suva.

The 27 member countries of the EU have enormous economic impacts as together the world's largest provider of development assistance, to 150 countries; in 2006 European aid to Pacific countries increased by 9.5 percent 
to EU 2.93 billion (US\$3.99 billion) (EUAustralia, 21 March 2007). At the April consultations the EU would announce that a total of F\$400 million (\$US245.4 million) in multilateral assistance was 'at stake or delayed' as a result of the December coup. (It included F\$44 million-US\$26.9 million—for European Development Fund programmes for school rebuilding, civic and voter education, and a solid waste environmental scheme; and F\$274-US\$168 million--for sugar industry restructuring, mostly unallocated at the time). It said: 'The European Union considers that the military take-over ... constitutes a breach of the essential elements of Article 9 of the Cotonou Agreement ... The EU encourages Fiji to examine the roots of the "coup culture" and the means to eradicate it' (EC Pacific, 18, 19 April 2007).

Koos Richelle, Director General of the EU's Europeaid Cooperation Office, had pointed out (EUAustralia, 21 March 2007) the importance of the organisation's Suva office as the centre of the only regional system where all national programmes were integrated into a single regional strategy-focusing on environment and sustainable development. He said the involvement could be intimate, with offices also in Auckland, Port Moresby and Sydney (and a representation in Solomon Islands): 'We get good political reports when there are problems as in Fiji ...'

It is a key fact of the situation of any region in a 'globalised' world order that organised outside agencies will be involved in political and economic affairs, and in the process will stake out positions of their own. It raises of course the demand that all implications of such engagements must be reviewed, while the realpolitik of the situation, that 'outside' agencies hold money, power and influence remains to be faced. In 2007 spokespeople for the European Commission, on Fiji, while stressing that humanitarian assistance was exempt and that all avenues to agreement would be attempted, spelt out conditions for agreement forthrightly. In one instance: 'If the responses are not satisfactory of course we will have to take measures to totally or partially suspend our aid' (Amadeu Altafaj, EUAustralia 4 March 2007). In another: 'We don't like coups d'états' (Pietro Petrucci, EUAustralia 9 December 2006).

Interventions by non-governmental agencies are no less driven by values and performance standards, which, not so much ordained from outside, will have fervent local supporters or, as in the case with the Cotonou Agreement, will be formally embraced on both sides. For example: recurrent disputes between the anti-corruption body Transparency International and government 
figures in Papua New Guinea, with in 2003 its local director being brought before a Parliamentary Privileges Committee to receive the ire of Members aggrieved by an agency report (Duffield, 2006, p. 107). In another example: the critical international publicity campaign by Amnesty International documenting continued transgressions against human rights and the rule of law, as it monitored the return to democratic processes after the 2000 Fiji coup d'état (Amnesty International, 2003).

\section{Government agencies and NGOs}

The importance of international agencies in the Pacific region is well recognised, especially in development economics, campaigns for civic development and in cultural affairs. The work of government agencies and NGOs will be integrated, e.g. those like the Australian government's AusAID will disburse funds for community projects run by private agencies. The ubiquity and collective large scale of these agencies' operations is significant, along with their policy impacts, as in the strong example above of the EU enforcing its Cotonou standards; and there is the third important aspect of the global connectedness of these organisations. Through multilateral agencies of many kinds, for good or ill, small populations generally with weak economies, dispersed over vast areas, are brought into a world system of power relations, business, economic management and cultural interfaces.

Questions arise: How do these organisations operate? What kinds of value formation and policy making will inform what they decide to do? Further, there is the strategically important aspect of mass media and communication management. State agencies and NGOs engage in mass communication across distances because they operate in many dispersed places, and because they must deliver messages to many publics, viz political constituencies in donor countries, cooperating or competing agencies, and participants and recipients in the partner countries. Hopefully the study provided here of the very particular case of the International Crisis Group as an agency concerned with operating levers of power, will be a useful contribution to understanding of these core aspects of the movement, specifically with the NGOs.

The movement itself is populated by a large range of diverse often wholly unconnected organisations; some are governmental or wholly government-sponsored, some formed by religious or benevolent institutions, others founded by small groups, many international but many also locally-based. 
As an example of the diversity and also connectedness of operations, the Regional Secretariat of the SSPI (Foundation of the Peoples of the South Pacific International) lists donors including the European Commission and NZAid, and 'metropolitan' affiliates, e.g. organisations in Australia and the United States, along with several regional affiliates; and advertises four local NGOs interested respectively in social, economic and political issues in Fiji; civil society development in Fiji; a body that provides theatre performances linked to development in Vanuatu, and a pan-Pacific women's organisation (FSPI).

The inventory provided by the leading Directory of Development Organisations, from NonProfitExpert.com, concentrates mostly on the economic development sector and includes banks and other financial institutions, embassies, unions or business organisations, certain national government departments, and churches, along with local community organisations and the classic international aid or rights agencies like Caritas or Transparency International. The locally based formations will have links to 'metropolitan' organisations or governments, especially as funds providers. Together this cosmopolitan collection of agencies makes a concerted effort and generates major impact. Among the larger concentrations there are 120 such offices listed for Papua New Guinea, 12 being major overseas-based agencies; there are 91 listed for Fiji, 76 in Vanuatu, Samoa 55, New Caledonia 46, Solomon Islands 46, and 42 in Tonga.

\section{NGOs: The International Crisis Group}

The purpose here is to provide a detailed study of the functions of Crisis Group as a leading international conflict resolution organisation, which has achieved prominence through its sophisticated mode of operation and demonstrated influence in circles of power, and to examine the extent to which it exploits and depends on mass media. By extension this will permit us to draw conclusions more generally about internationalist action in response to local or regional crises, and also to understand better the place of mass media in advocacy and in influencing conflict resolution. The intention of the author is to demonstrate how the organisation functions and show the level of importance of its media operation; noting outcomes from its work (including outcomes of media initiatives, and also media phenomena as outcomes of initiatives generally). 


\section{Methodology}

The method of research has been to examine a key sampling of documents routinely kept by the organisation as an instructive record of its operations. As it is concerned with advocacy, where measurement of achievements can be elusive, an ongoing journal is helpful to show outsiders the scope and character of operations. A self-critical, non-confidential (if unpublished) record also will give assurance of transparency such as the organisation promotes in public life generally, and help its own officers to make improvements. The documents in question are: Annual reports of Crisis Group in recent years, 2004-2006 inclusive, offering a middle-term account of its concerns and activities; monthly Advocacy Reports circulated within the organisation, for the three months October to December 2006, inclusive; and the monthly playbook or compilation of media 'cuttings' kept by Crisis Group, for the same three months' period. The full set of reports and briefings for 2007 to date was also reviewed.

The last quarter of 2006 was chosen as the most recent and complete compilation available when the study was commenced in January 2007. Crisis erupts or develops in any month; events and processes will follow unpredictable courses; the author considers no specific period can be regarded as typical or untypical for the incidence of activity. However the archive of Crisis Group public documents-reports, regular regional briefings, speeches, articles commissioned for leading newspapers-has been checked also to identify the most recently occurring issues, in the Asia Pacific region, from the beginning of 2007. Principles and operational concepts driving the work of the Crisis Group and inherent in its activities are investigated. These are clearly implicit in documentation from the organisation, most notably the annual reports and the speeches or writings of its executive members.

\section{Crisis Group: Rationale, structure and functions}

Crisis Group was formed in 1995 as an independent, non-profit, non-governmental organisation, with now more than 130 staff members on five continents, working through field-based analysis and high-level advocacy aiming to prevent and resolve deadly conflict. It grounds its approach in field research, engaging political analysts located within or close by countries at risk of outbreak, escalation or recurrence of violent conflict. It produces analytical reports containing practical recommendations, which 
are targeted at key international decision-makers. Therefore, as Crisis Group declares, it "works closely with governments and those who influence them, including the media, to highlight its crisis analyses and to generate support for its policy prescriptions'.

The essential facts on organisational structures and practice are clear from its own sources, the information above obtained from the web document 'International Crisis Group: working to prevent conflict worldwide' (ICG, Home). Crisis group has its headquarters in Brussels and advocacy offices in Washington, New York, London and Moscow. It currently operates 17 field offices with analysts working in more than 60 crisis-affected countries and territories. ${ }^{1}$ It has an annual budget of about US\$14 million, gathered from a long list of governments, charitable foundations, companies and individual donors (ICG, Home).

It is above all an advocacy organisation grounded in field research. Analysing information collected in the conflict regions, it transmits recommendations to people able to take political decisions necessary to prevent or end the violent conflict in question. Promoting particular courses of political action on such matters, Crisis Group has had to address questions of the rightfulness and legitimacy of international intervention, which as a last resort can also include military action; and as essentially a hard-headed, pragmatic operation, it avers that it looks beyond ideology seeking to find solutions that will simply work.

Face-to-face meetings with decision-makers are a core component of its advocacy work; talking with the 'people who matter' and giving them information from the ground that they need along with a comprehensive analysis of the problem; promoting informed decisions. The organisation then magnifies the transmission of its messages through extensive yet targeted work with the media. To be seen and noted in prominent media outlets in itself adds to the organisation's recognition and status, and therefore influence, but that is treated as a secondary goal of its communication strategy. The prime focus of Crisis Group's media work is essentially to reach in public those same decision-makers it meets regularly in private. Thus, unlike many NGOs, which have a media-centred approach to their work and aim for mass media impact to inflate general public awareness, hoping this will pressure elected officials to make the right decisions; the International Crisis Group aims to address those at the levers of power directly, both in closed-door meetings and through elite media. 
At the highest level, this extends to drawing on the organisation's president and Board of Trustees-generally former ministers, including two former heads of state- to take part in making approaches and presentations to top government decision-makers. Along with the president and chief executive, Gareth Evans, previously Australian Foreign Minister 1988-96; the board's co-chairs and leading advocates are the former European Commissioner for External Relations Christopher Patten and former US Ambassador Thomas Pickering. The organisation proudly uses testimonials from distinguished international figures. In particular Kofi Annan as UN Secretary General, provided a comment useful for the present review, showing awareness of the motivation, mode of operation and high practical value of the group's work:

You have made the International Crisis Group a global voice of conscience ... Your mediation work-and your leadership in early warning and conflict prevention-have been enormously important. So has your intellectual contribution to finding new approaches to long-standing conflicts. Your well researched and carefully argued reports have greatly helped us in understanding the origins and complexities of the conflict in which we become involved-often at short notice (Annan, 2002).

\section{Operations of the ICG over three months}

The advocacy reports of the organisation for the last quarter of 2006 provide a comprehensive picture of Crisis Group's primary activities in the period. They have been dissected to discern the main elements; especially the policy recommendations the organisation's representatives are promoting; the distribution of its efforts worldwide; and the relationship between media work and other aspects of the operation. The information was tabulated and divided into six categories: the main topics targeted in the month under report; subsidiary topics; the activities or initiatives undertaken by Crisis Group; specific media initiatives; general outcomes, and media outcomes. The three working tables produced for October, November and December displayed the data for ease of overview. To illustrate, an extract from one table is given as an appendix.

For definition, 'media' refers to activity carrying out the three functions mentioned above: work under a communication strategy to craft information, either to be taken up by general news media or published directly by Crisis Group, to help explain the substance of its policy recommendations; 
secondly, promotional work, to draw attention to activities of the organisation, e.g. mounting a publicity campaign in support of advocacy activity where public awareness may be a useful complement to that work; and thirdly, given relatively less importance by this organisation, more reactive management of media, e.g. handling casual inquiries from journalists. 'Outcomes' are events, developments or even declarations by power-holders which can be linked to advocacy by Crisis Group, e.g. formulation of a UN Security Council (SC) resolution containing principles put to members of the SC by Crisis Group, where after the event diplomats in the case agreed the group's advocacy activity was influential in that case. These outcomes will usually be claimed as such in monthly reports.

Distinctions between activities and outcomes can be somewhat blurred. For example, for a political advocacy group to obtain direct private access to heads of major governments or governmental agencies like the EU or UN, is an achievement in itself, but would not count as an outcome unless that act was seen to deliver influence. The following sections draw on monthly Advocacy Reports.

\section{Operations in October 2006}

The month's activities were led by a coordinated lobbying and publicity campaign on Crisis Group's Middle East Initiative. It began with a statement supporting a comprehensive settlement of Arab-Israeli conflict, signed by 135 'respected global leaders' - primarily former presidents, prime ministers and foreign ministers-using paid space in the Financial Times, and The New York Times, and freely offered space in Le Monde and Ashraq al Awsat (4 October 2006), and near simultaneous publication of an advocacy report, To Reach a Lasting Peace (5 March 2007), filling the details of a peace initiative. This was a characteristic operation, both texts opening with declarative style, assertive comment and an overall tone of assurance. It was forthright with advice, founded as it was on solid research and a comprehensive analysis of seemingly intractable problem. Crisis Group does not shy away from criticizing positions taken by any party, in this case determining which parties ought to take the lead in new Middle East peace initiative: 'American and Israeli reluctance to move, coupled with extreme fragility of the situation, means that others- the UN, EU and Arab world-must now step forward with fresh ideas and initiatives, optimally to persuade 
Washington to act ...' The report proposed content for the UN Security Council Resolution. As outcomes; it was seen as significant success that 'To reach a lasting peace' was Crisis Group's most downloaded report for the month-25,611 copies were accessed.

A report on Darfur, Getting the UN Into Darfur, was published on 12 October 2006, as the platform for direct lobbying of the UN Security Council, and a UN Undersecretary General, on themes that took in 'acceptance of a firm stand vis-a-vis Khartoum ... including economic measures, petroleum sanctions, a no-fly zone, disinvestment, and planning for possible military engagement'. There were meetings with like-minded NGOs, notably in London, in the context of an ongoing public campaign of activities, and a meeting with 'high level Administration contacts in the US'. Once again there was a precipitating factor, a 'deteriorating situation' in Darfur. It was remarked that the US Congress and Senate had asked the Arab League to exert pressure to stop a Sudanese military offensive, placed in the 'outcomes' column on trust that Crisis Group lobbying had contributed to the legislators' thinking.

Another public document, a briefing paper on the elections in the Democratic Republic of the Congo (2 October 2006), aimed to ensure a positive follow-up to the first round of voting. Crisis Group called for an extension of the EU military force's mandate and wrote on this to the German Chancellor representing the European Council presidency. Contact was made with intelligence officials and experts on African affairs in Washington. A commentary article signed by co-chair Chris Patten and published in Suddeutsche Zeitung at the end of September actually led the charge and helped achieve a major breakthrough after sparking a serious debate in German media. Consequently the Defence Minister Franz Josef Jung in October publicly left open the option of prolonged EU troop presence in some form.

Advocacy in October on Cote d'Ivoire was timed to co-ordinate with a UN Security Council debate and urged 'rapid and united Council action'. Crisis Group worked through the Japanese Ambassador Takahiro Shinyo as UN envoy and noted — as outcomes — that its points had been delivered to the Cote d'Ivoire government. The policy recommendations also matched the content of the Security Council resolution passed on 1 November 2006.

A report was published on Colombia coinciding with a forthcoming trip there by the US Undersecretary of State Nick Burns, whom the Crisis Group 
was able to brief beforehand. As outcomes, Burns raised Crisis Group recommendations and the visit was subject to widespread media reportage. To keep Afghanistan and Pakistan 'on the international community's radar', high level meetings and briefings were reported in Paris, Copenhagen and Brussels, with NATO, the EU, MEPs and national MPs, and national ministers. The South Asia Programme Director briefed European press.

The insistence on 'high level' connections is evident in other activities from that month. The NATO Secretary General Jaap de Hoop Scheffer, and EU High Representative Javier Solana, met the Trustees on a 'range of issues'. Evans met UN Ambassadors on the Congo elections, Darfur, the South Caucasus, the Arab-Israeli conflict, 'the need for rather stiff sanctions against Uzbekistan', and 'dangers of delay on Kosovo'. Ambassadors from five countries attended a New York reception held for prospective members of Crisis Group's Advisory Council. Crisis Group also participated in a round of events in the United States on its theme of Women in Peacebuilding, involving prominent activists.

\section{Operations in November 2006}

With its declared topic 'countering the insurgency in Afghanistan', in advance of a UN Security Council mission to Afghanistan in mid-November, Crisis Group provided field-based input, which it considered to have helped shape the terms of reference for the visit. Among outcomes, its report, Countering Afghanistan's Insurgency: No Quick Fixes, was downloaded 26,000 times from its website and generated 'extensive positive feedback from the policy community'. The report was made obligatory reading within NATO, and in Kabul, Crisis Group's senior analyst discussed it directly with the NATO Senior Civilian Representative.

Because of the 'deteriorating situation in Somalia', Crisis Group issued on 27 November 2006 a conflict risk alert warning, in which it attacked a draft resolution on Somalia the US was intending to present to the UN Security Council, to authorize the lifting of the UN arms embargo. It said the resolution would aid one side and could trigger all-out war. 'The Council should apply maximum pressure on both sides to resume negotiations,' it said.

As part of this Somalia initiative the Washington and Brussels offices worked through news media, calling on contacts and giving broadcast interviews. The exposure was accompanied by discussions with US 
Administration officials and all Security Council members. An op-ed was placed in the Boston Globe, circulated by the EU to all Ambassadors. On outcomes, the warning was 'picked up widely and appears to have been influential in a 28 November retreat by the State Department', which enabled the UN resolution to be delayed.

Again provoked by a deteriorating situation, in Darfur, the International Crisis group 'continued to push its message that sustained pressure was required to change calculations of the Khartoum regime'. One outcome was not happily received: senior officers met a key US official in Sudan, who expressed 'his desire to pursue multilateral dialogue with Khartoum before considering more coercive measures'. Efforts on Darfur would be heavily intensified in the following month.

For the Democratic Republic of Congo advocacy centred on 'effective peace-building measures, addressing integration of the armed forces with demobilisation of opposition militia, strengthening of Parliament, and continued presence of a strong UN force (MONUC)'. Relevant officials were contacted through the Brussels roundtable, and advocacy calls at the United Nations. On Kosovo's final status, there was joint hosting with the Belgian UN Mission of a Kosovo roundtable 13 November 2006, employing expert advice, viz former Special Representative of Secretary-General, Soren Jessen Petersen, and also publication of a new report, Kosovo Status: Delay is Risky.

Crisis Group had published nine of its own articles/op-eds in the reporting period, on Uzbekistan, Somalia, the Middle East (Syria), the International Criminal Court, and children in war: in Liberation, The CS Monitor, Guardian, Al Hayat, FT Deutschland and Transitions Online. Visits to the website hit a new high of 487,785 in November, while it had 9 million hits and 3.5 million page views. The list of email contacts increased by 10,000 to 90,000 in total.

\section{Operations in December 2006}

Calls for 'stronger pressure on Sudan'. Crisis Group advocacy, responding to 'lack of political progress', 'stepped up a gear', proposing increased pressure on Sudan to accept a proposed hybrid African Union/UN peace-keeping force in Darfur. Its campaign had the Crisis Group president and other senior figures employing access to key leaders, and added mass media activity as reinforcement. Advocacy meetings were obtained with the heads of the British and 
German governments and the incoming UN Secretary General Ban Ki-moon, ('highlighting the need to move tough economic, financial and personalised sanctions, including on individuals in the regime, if no acceptance of an AU/UN force emerged by the end of December'). Other senior US officials were contacted, including US senators preparing a resolution passed on 9 December 2006 urging implementation of the agreement for a peacekeeping force under UN command.

Parallel media action was organised Gareth Evans and Ken Roth, Executive Director of Human Rights Watch, held a press conference on 13 December 2006 in Brussels, issuing a statement calling on the EU to support tough new action against Sudanese leaders. For outcomes during the month: Britain's Prime Minister Tony Blair spoke of a possible no-fly zone over Darfur, and Germany's Chancellor Angela Merkel noted that among many security tasks Germany would do 'what it had to' in the EU and G8 presidencies. Crisis Group campaigned to 'highlight the Pakistan government's failed policy regarding Taliban-linked militants in the Federally Administered Tribal Areas'. A report, Pakistan's Tribal Areas: Appeasing the Militants (11 December 2006) initiated intensive debate in Islamabad, widely reported in national and international media. Crisis Group raised the report with American legislators, the State Department and USAID, and UN agencies. It was quoted by BBC, CNN, International Herald Tribune, The New York Times, Boston Globe, The Guardian and Washington Post, and by regional press including Dawn, The News, Daily Times, The Hindu and The nation. It became Crisis Group's third most downloaded report for the year $(31,669)$. This kind of success in obtaining exposure for an argument was seen to have had a material outcome: 'It determined denials by government officials on increased cross-border incursions since signing of the September agreement with pro-Taliban militants'.

On Iraq 'proactive Crisis Group advocacy' continued following the long-awaited U.S. Baker-Hamilton Report, proposing a multinational effort. The Crisis Group, After Baker-Hamilton: What to do in Iraq (19 December 2006) generated substantial media attention ahead of President George Bush's promised new strategy announcement in January. The report argued that BakerHamilton did not go far enough in its prescriptions and called for a 'clean break in the way the US and other international actors deal with the Iraqi government, and the way the US deals with the region'. If extensive coverage 
in mainstream media is an outcome in its own right this was persuasive effort; the document was outlined in numerous wire reports and newspaper articles including The Daily Star, The Independent and Washington Post-together with placement of a supportive op-ed article in the Financial Times.

On Somalia, prior to the Ethiopian military offensive, Crisis Group targeted UN Security Council members, objecting to the US draft SC resolution that would have permitted Ethiopia to participate in a regional intervention force. UN officials concurred, and the SC later unanimously adopted an amended resolution, authorising deployment of the proposed IGASOM peacekeeping force-but excluding frontline states from it (one being Ethiopia). Several UN delegations attributed this in large part to Crisis Group's efforts. However events quickly developed to overtake the Crisis Group efforts, as the TFG (provisional government) and Ethiopian army evicted the CSIC (Islamic Courts) from major towns. 'Massive casualties and internal displacement have been reported and a scramble ensued in Mogadishu as rival militias and faction leaders returned to their fiefdoms,' Crisis Group reported.

On outcomes in mass communication including media: Crisis Group published nine articles/op-ed on Somalia, the Middle East (Iran-Syria talks), Aceh province in Indonesia, Congo, Oriente Proximo, Nagorno Karabakh, Bolivia and Columbia; in Al Hayat, Jakarta Post, Boston Globe, El Mondo, Financial Times, openDemocracy.net, La Razon, The Nation (Kenya) and Le Temps. Visits to the website hit a new record at 495,467. The list of email contacts totaled nearly 92,000. The organisation was able to congratulate itself on 'another year of impressive growth' in its digital communication efforts. In total there were 4.85 million visits to the website in 2006, 1.5 million higher than 2005 and 3million higher than 2004. Total reports downloaded over the year increased to 3.1 million from 2.3 million in 2005 .

\section{Operations of Crisis Group in Asia-Pacific 2007}

Crisis Group maintains a 'crisis watch' on 79 countries or territories, issuing monthly 'alerts' in cases of conflict where its analysts judge that international intervention would be warranted. Its watch list, as can be seen from the above, indicates its current preoccupations are with ongoing major distress in Darfur and Western Africa, Kosovo, former Soviet republics in Central Asia, and the Middle East. Yet its interests are comprehensive and far reaching and as well the list currently includes Fiji, Timor-Leste (East Timor) and Tonga (since 
rioting in November 2006), Indonesia, the Philippines and Taiwan Strait. Apart from Indonesia and Timor-Leste troubled regions of the AsiaPacific have not received the full treatment of intensified Crisis Group research, high level lobbying, placement of signal articles with elite media outlets, and active campaigns generating attention in general mass media; but watching briefs that are now kept put target areas on the agenda for intensified work wherever and whenever it might be seen as warranted. Each monthly Crisis Watch bulletin identifies priority cases, noting whether their situation has deteriorated or improved. In June 2007 Fiji, following the 2006 coup, remained in this special watch category, classed as 'unchanged' (ICG, 1 June 07). The country's first notification since its most recent coup d'etat had been made in January (ICG, 2 January 2007), in the category of 'potential or actual crisis situations'. Since January 2007 Crisis Group's monthly Asia Briefing has analysed local issues in the conflict in Indonesia Papua (ICG, 19 July 2007), and other issues within Indonesia: local power struggles in Maluku (ICG, 22 May 2007); current status with the insurrectionist group Jemaah Islamiyah (JI) (ICG, 3May 2007, 24 January 2007), and stabilization in Aceh (ICG, 22 March 2007). Other interventions on Indonesia included published articles by Crisis Group's long-standing analyst on that country, Sidney Jones, on future prospects (3 January 2007) and the capture of the JI leader Abu Dujama (7June 2007). The parliamentary elections in Timor Leste produced a notice in the June Asia Bulletin (ICG, 12 June 2007), stating 'no one is offering concrete solutions to the country's many problems'. Timor Leste had been put under Crisis Watch in the lead-up to the voting, in the March bulletin (ICG, 1 March 2007).

\section{Main characteristics of Crisis Group}

Crisis Group is an advocacy group seeking policy changes, though not for direct material benefits to itself--unlike for instance an industrial lobby interested in tariff changes or getting access to natural resources. It works in public diplomacy, and transparency is a hallmark of its work. Its positions and goals are publicly stated, and they are defended by intellectual argument rather than coercive pressure, though where such pressure is attempted, e.g. by adding media efforts, it is not a concealed process.

The objectives formulated for each advocacy exercise are deliberate, focused on securing definite, identified actions from specified governments, multinational organisations and other key players, and these objectives 
are couched in the most forthright terms. The mode of operation is highly pragmatic: as shown in the paraphrasing of a three months' diary, above, timing is considered for each initiative and a reason given for the initiative at that time. Goals can be shortterm; the approach is incrementalist, one reform or one successful change on the ground, at each time. The pragmatic approach obviously will be compatible with having a strong media side to the enterprise; promotional work and public advocacy must be more functional when the goals are made clear.

As with many an exercise in public diplomacy there is a well organised mass media operation.

The unambiguousness of Crisis Group messages helps it to get those messages quoted in news media, which may enjoy ferreting out hidden truths but overwhelmingly lack patience for complicated, coy, ambiguous points of view. The media effort is measured; resources are applied to specific projects and addressed principally to elite news outlets known to be used by members of the political establishment.

More than its media connections, the Crisis Group demonstrates privileged lines of communication to the upper echelons of leading institutions. It is well connected to the United Nations Organisation, the European Union and NATO, and to leading elements within the United States government and political community. These organisations are chosen largely because they can deliver outcomes; they are powerful in the world. Likewise other institutions anywhere will be approached where engaged in a running issue. The relationships are cultivated both in conventional ways, and through special services that the organisation can offer in its public affairs function, as the provider of well-researched arguments. It serves as a free, good quality, policy consultancy for persons at the level of, for instance, a senior UN executive. A report or briefing paper is usually published with each new initiative, and Crisis Group is known for the strong intellectual quality of its inputs.

The organisation has also availed itself of another very powerful resource through engaging with senior personnel who have ended their main life careers. It gathers former leaders willing to share their advanced knowledge, contact books, judgment and expertise. Bearing in mind that the objective is a humanistic good, to avert violent conflict across the globe, it has a strongly altruistic aspect. 


\section{Ethos and doctrine}

What are the terms of reference which provide motivation for the International Crisis Group? What is its guiding philosophy? Perhaps surprisingly, the organisation has no institutional ideology, as it makes clear from its own statements, e.g. the annual reports. The organisation exists to prevent and resolve deadly conflict simply for the purpose of reducing human suffering, and its approach to and recommendations for each specific conflict are tailored to fit the needs of that particular situation. This naturally leads to contradictions between the organisation's approach to conflict X and its approach to conflict $\mathrm{Y}$, but, the reasoning goes, if $\mathrm{X}$ and $\mathrm{Y}$ are unique conflicts with local causes and consequences, then why should anyone expect their solutions to be the same? In this reasoning, it says solutions to complicated political problems cannot be shoe-horned into any one-size-fits-all model. Despite this-or, really perhaps because of this - the organisation believes it commands strong loyalty and is highly regarded around the world and across the political spectrum.

That all said, the doctrine of the 'Responsibility to Protect' (R2P), in international law, does provide a recurring background theme to some of the more high-profile advocacy the group is involved in, such as its work on Darfur. The report of the International Commission on Intervention and State Sovereignty (2001) provides a comprehensive guide to the issues and evolution of debate. It proposes that state sovereignty implies responsibilities, which can be abrogated if the state in question is unwilling or unable to halt mass violence due to internal war, insurgency, repression or state failure. In short, the international community, acting though the UN Security Council, has the responsibility to protect civilians facing mass atrocities if their own state cannot or will not do so.

Whereas Crisis Group is not ideologically-driven, where principles are debated, as in public presentations by Evans as president (Evans 2006, 2006A), arguments will be drawn from history and jurisprudence. For example discussions on R2P emphasise legal authority described in terms of Security Council responsibilities under Article 24 of the UN Charter, or authority drawn from obligations under human rights declarations, covenants and treaties. Debate on the responsibility of governments considers the historical fact of many non-state organisations increasingly taking part in humanitarian intervention, sometimes against claims of state sovereignty under UN Charter (Article 2.1). 
Other organisations share Crisis Group assumptions and sympathies. The United Nations itself has applied the R2P principle to its objective of freedom from fear, in the light of today's focused worldwide interest in development, security and human rights (see Secretary General's report, 2005). The European Union has followed a similar line. Citing a need for legal bases for its human rights and democratisation activities, it adopted two Regulations, 975/1999 and 975/1999, on democracy and rule of law, and on fundamental freedoms (EC External Relations, 2007).

\section{Communication management and mass media}

By making recommendations for particular policies, Crisis Group clearly cannot fall into the non-committal branch of public debate that admits all possibilities and views for an even-handed hearing. No fence-sitting allowed. Nevertheless its media output is a journalism of truth, as there is a certain probity required where Crisis Group publishes on its own account, most distinctly with the regular monthly output of ten articles contributed to leading journals. It is also journalism well inside the mainstream of establishment thinking, if at times sailing close to the horizon of what is 'politically acceptable' in elite circles. As the titles of the newspapers indicate, e.g. Financial Times, Le Monde, Washington Post, Asharq Al Awsat, the group seeks influence with readers who have power to effect change. Therefore it needs to itself make the grade in terms of meeting the prevailing journalistic standards of fact-finding, new ideas and important disclosures, to get its message always into at least one serious political journal of record in capital cities where it is operating.

This approach is common enough for advocacy groups or institutions able to generate a large volume of new, researched information. The Spokesperson's service of the European Commission though making an effort to be open to all, typically concentrates on main quality outlets, as indicated in the selection of titles that appear in its daily playbook of media cuttings--similar to those of Crisis Group (DG Communication EC, 2006). The bigger newspapers with the most interest in all aspects of EC activity will employ larger and more specialised bureau staffs in Brussels. In a widely acknowledged 'two-step' communication flow, messages are got through to a corps of best-informed readers via such 'first-line' media, and then the news may be lifted or quoted, or followed-up by others (See AIM Research Consortium, 2007, pp. 157-8). 
The second part of the Crisis Group operation broadens the approach, as it generally runs one or two main campaigns each month, where the media operation will gear up into a greater level of activity than for the average report release. Targeted media contacts, media releases and news conferences are used to promote the researched field report-with recommendations for action at the centre of the campaign.

As Crisis Group said in its 2006 annual report, 'we have tried to avoid "talking head" instant commentary not directly related to our own reports'. While staff appeared frequently in broadcast interviews, it is not set up as a publicity machine offering comments on any topic. Of more interest to the organisation, direct input into the 'quality' media sector was strong: 5,535 mentions in major media around the world in 2006 (as compared to 4,501 for the whole of 2005, 3,166 in 2004 and 2,503 in 2003). These numbers do not include republished articles and reprinted wire copy: counting such republications, the number of mentions in 2006 jumps to 18,066 (compared with 10,677 in 2005 and 5,419 in 2004). In addition, Crisis Group Board members and staff published 142 comment (op-ed) pieces in 2006 (compared with 129 in 2005, 105 in 2004 and 63 in 2003) (Annual Report, 2006).

The organisation's own monitor of news media directly initiated from its in-house sources tracks mentions of its work. This monitor showed as might be expected that news items generated by the office were being picked up by the targeted media outlets, but also by a broader range including international radio services (BBC, RFI, DW, VOA in particular), and newspapers in all regions where issues were being contested. The main national newsagencies (including Reuters, DPA, AFP, UPI, Bloomberg) were heavily represented in the monitor, with a multiplier effect for those reports. Reports were consulted for October, November and December 2006, in each case telling the topic or brief content of each news story, its source, applicable world region, and the agency or media outlet handing it. As a diligent though understandably not exhaustive monitor of the world news media it demonstrates high exposure for the organisation.

The quoted sources are mostly listed as 'Crisis Group' itself, presumably taken from central media releases, with also 10-20 other personnel of the organisation quoted in each of the monthly monitors. It gives an impression of many co-ordinated voices operating across a broad range. All of the geographical regions of activity were well represented except for Europe and 


\begin{tabular}{|l|c|c|c|l|}
\hline \multicolumn{1}{|c|}{ Table 1: Summary of International Crisis Group media usage reports } \\
\hline Month & $\begin{array}{c}\text { Total } \\
\text { reports }\end{array}$ & $\begin{array}{c}\text { Crisis } \\
\text { Group } \\
\text { originated }\end{array}$ & $\begin{array}{c}\text { Agency } \\
\text { reports }\end{array}$ & \multicolumn{1}{|c|}{$\begin{array}{c}\text { Topics most } \\
\text { mentioned }\end{array}$} \\
\hline $\begin{array}{l}\text { October } \\
2006\end{array}$ & 529 & 131 & 123 & $\begin{array}{l}\text { North Korea, Darfur, } \\
\text { less of Thailand and } \\
\text { Mid-east }\end{array}$ \\
\hline $\begin{array}{l}\text { November } \\
2006\end{array}$ & 352 & 143 & 93 & $\begin{array}{l}\text { Pakistan-Afghanistan, } \\
\text { N.Korea,Israel-Iraq- } \\
\text { Lebanon, Kirghkistan, } \\
\text { Zimbabwe, } \\
\text { Afghanistan }\end{array}$ \\
\hline $\begin{array}{l}\text { December } \\
2006\end{array}$ & 536 & 197 & 137 & $\begin{array}{l}\text { Middle East incl. } \\
\text { Fatah-Hamas, Central } \\
\text { Asia, Aceh poll, } \\
\text { Pakistan-Afghanistan, } \\
\text { Horn of Africa-Darfur }\end{array}$ \\
\hline
\end{tabular}

North America, where violent conflict was at lost in abeyance. The synopsis in Table 1 indicates the main issues in play during one month. On content of coverage, it identifies two main sets of reports, being those obviously generated directly from Crisis Group releases, and news agency copy.

Additional to this work with mass media, Crisis Group puts emphasis on 'getting the message out' directly to an expanding mailing list of 4200 'senior policy makers and those who influence them' (in 2005); by email with attachment of reports and papers, to over 17,000 'Influentials', and to 80,000 web subscribers. Added to large numbers of page visits to the central website and downloads of reports, the Crisis Group is clearly keeping pace with the breaking-up or pluralising trend in media use associated with accelerated use of the internet.

\section{Conclusion}

Crisis Group stands apart from many other non-government organisations through its commitment strictly to research and lobbying at centres of power. Its analysts will do field work in dangerous settings to gather reliable information, but it is not a relief organisation and so does not operate prominently in the field. Similarly it has no profile to maintain in mass media, on the 
ground, no call to demonstrate its work by publicising actions of its officers in war zones or refugee areas, whereas in the case of many organisations, e.g. ICRC, the media witness may be highly important for their protection and in garnering international public support. A further key aspect of Crisis Group, for the present discussion, is that in its work against violent conflict it sets out to function as part of a broad international scheme. Conflicts in remote parts of Africa or Central Asia, or for that matter on isolated Pacific islands, are scrutinised and brought to notice in world forums. The practicability of such work builds on the fact of global integration; no region is itself an 'island', autonomous of movements in the wider world, ever able to escape its afflictions and interventions. Non-Government Organisations like Crisis group with their links to governments and other sources of influence participate in management of global business-including the business of the smallest countries.

The International Crisis Group in one sense is a model, where it has achieved startling success in terms of its ability to demonstrate direct influence on the management and outcomes of crisis situations. It has participated in the development of a community of non-government agencies active in the conflict resolution field, and in formulating statements of guiding principles for such organisations. In the process it has contributed to a change in practices, especially in altering the prerogatives and behaviour of government agencies. Where crisis situations are sometimes said to be fields of danger and opportunity, this organisation has made its plans to alleviate danger and suffering, and generate opportunities for positive change.

Media are key to its approach, and again it provides a model for certain purposes, where it concentrates on engaging elite media rather than highervolume mass media. Because of the fixed approach in its core activity, in dealing directly and predominantly with senior figures in institutions, its media plan, a 'two step' approach concentrating on use of restricted 'upper echelon' outlets, has easily fallen into place. With its transparent and well researched 'pitches' to media it plainly obtains a friendly and accommodating response with good levels of usage. Furthermore it has come to use its media service also as an integral part of the research and communication process, through the mounting of recurrent campaigns around issues of the month. In addition it now relies strongly on distribution of its information in millions of packages, via digital media. Media representation, and 'successes' with heavy 
coverage of its leading initiatives are treated as valued outcomes of activity. Crisis Group like many other organisations has taken on board that communication, in diverse forms, is playing an ever larger and more central role in all social, economic and political activity in this century.

\section{Note}

1. Intervention sites: In Africa, this includes Angola, Burundi, Democratic Republic of the Congo, Eritrea, Ethiopia, Guinea, Ivory Coast, Liberia, Nigeria, Rwanda, the Sahel region, Sierra Leone, Somalia, Sudan, Uganda and Zimbabwe; in Asia, Afghanistan, Indonesia, Kashmir, Kazakhstan, Kyrgyzstan, Myanmar/Burma, Nepal, North Korea, Pakistan, Sri Lanka, Tajikistan, Timor-Leste, Turkmenistan and Uzbekistan; in Europe, Albania, Armenia, Azerbaijan, Bosnia and Herzegovina, Georgia, Kosovo, Macedonia, Moldova, Montenegro, Serbia and Turkey; in the Middle East, the whole region from North Africa to Iran; and in Latin America, Bolivia, Colombia, Haiti and Venezuela.

Currency conversions: dcerates.com (2 September 2007)

\section{References}

AIM Research Consortium (Ed.). (2007). Understanding the logic of EU reporting from Brussels: analysis of interviews with EU correspondents and spokespersons. Brussels: Adequate Information Management in Europe (AIM)Working Papers.

Amnesty International Report, 2003. (2003). - Fiji. Retrieved on 2 September 2007 from http://web.amnesty.org/report2003/fiji-summary-eng

Annan, K. (2002), Kofi Annan, United Nations Secretary-General. Retrieved on 3 March 2007 from www.crisisgroup.org/home/index.cfm?id=1205\&l=1

Duffield L. (2006). Media and government relations in Papua New Guinea. In Papoutsaki, E. and D. Rooney (Eds.), Media, information and development in Papua New Guinea. Madang: DWU Press, Madang.

Evans, G. (2005). Keynote Address by Gareth Evans ... to London School of Economics/Kings College London Conference on Ethical Dimensions of European Foreign Policy, London, July 1.

Evans, G. (2006). Address by Gareth Evans ... to Foreign Policy Association 'Offthe-Record' Lecture Series, New York, December 6.

Evans, G. (2006a), The responsibility to protect: from an idea to an international norm; keynote opening address to the Chicago Council on Global Affairs et al Conference on 'The responsibility to protect: engaging America', Chicago, November 15.

Evans, G. and M. Sahnoun (Co-chairs). (2001). The responsibility to protect: report of the International Commission on Intervention and State Sovereignty. Ottawa: International Development Research Centre. 
EUAustralia Online (2006, December 9). Fiji aid and trade in doubt, Brussels. Retrieved on 2 September 2007 from: www.euaustralia.com

(2007, March 4). Pacific countries get assurances on future support, Brussels. Retrieved on 2 September 2007 from: www.euaustralia.com

(2007, March 21). Aid boost to the Pacific, Brussels. Retrieved on 2 September 2007 from: www.euaustralia.com

The Fiji Times Online (2007, April 15). Group leaves for Brussels. Retrieved on April 152007 from: www.fijitimes.com

FSPI (Foundation of the Peoples of the South Pacific) (2007). Regional Secretariat. http://www.fspi.org.fj/Links/links-localngos.htm (2.9.07)

International Crisis Group, Home (2007, March 3). www.crisisgroup.org/home/index. $\mathrm{cfm}$

Jones, S. (2007, January 3). Watch out for more surprises in Indonesia, Australian Financial Review, Sydney.

(2007, June 17) After Abu Dujana and Nuaim, Tempo, Jakarta.

NonProfitExpert.Com, Directory of Development Organisations (2007, September

2). Resource guide to development organisations and the internet. Retrieved on 2 September 2007 from: www.devdir.org/oceania.htm

UNO, General Assembly (2005). In larger freedom: towards development, security and human rights for all; Report of the Secretary General; New York: United Nations.

\section{Published International Crisis Group documents referred to in text}

Crisis Group International, Annual Report, (2004, 2005, 2006). Retrieved on 20 March from: www.googlesyndicatedsearch.com/u/crisisgroup?q=Annual + Rep orts\&ie $=$ UTF-8

Fiji Coup d'état, Crisis Watch \#41. (2007, January 1). Retrieved on 2 September 2007 from: www.crisisgroup.org/home/index.cfm

Indonesia: Jemaah Islamiyah (JI), Asian Briefing \#127. (2007, January 24). Retrieved on 2 September 2007 from: www.crisisgroup.org/home/index.cfm

Timor Leste, Crisis Watch \#43. (2007, March 1). Retrieved on 2 September 2007 from: www.crisisgroup.org/home/index.cfm

Indonesia: Aceh, Asian Briefing \#61. (2007, March 22). Retrieved on 2 September from: www.crisisgroup.org/home/index.cfm

Indonesia: Jemaah Islamiyah (JI), Asian Briefing \#63. (2007, May 3). Retrieved on 2 September 2007 from: www.crisisgroup.org/home/index.cfm

Indonesia: Maluku, Asian Briefing \#64. (2007, May 22). Retrieved on 2 September 2007 from: www.crisisgroup.org/home/index.cfm

Fiji, Crisis Watch \#46. (2007, June 1). Retrieved on 2 September 2007 from: www. crisisgroup.org/home/index.cfm

Timor-Leste, Asian Briefing \#65. (2007, June 12). Retrieved on 2 September 2007 from: www.crisisgroup.org/home/index.cfm 
Indonesia: Local conflicts in Indonesia Papua, Asian Briefing \#66. (2007, July 19). Retrieved on 2 September 2007 from: www.crisisgroup.org/home/index.cfm

After Baker-Hamilton: what to do in Iraq, Middle East Report \#60. (2006, December 19). Retrieved on 20 March 2007 from: www.crisisgroup.org/home/ index.cfm? id $=4580 \& \mathrm{l}=1$

Darfur demands sanctions, not words: spreading conflict threatens millions in region, media release. 2007, December 13). Retrieved on 20 March 2007 from: www. crisisgroup.org/home/index.cfm?id $=4573 \& l=1$

Pakistan's tribal areas: appeasing the militants, Asia Report \#125. (2006, December 11). Retrieved on 20 March 2007 from: www.crisisgroup.org/home/index. cfm?id $=4568 \& 1=1$

Somalia conflict risk alert. (2006, November 27). Retrieved on 20 March 2007 from: www.crisisgroup.org/home/index.cfm? $\mathrm{id}=4520 \& \mathrm{l}=1$

Kosovo status: delay is risky, Europe Report $N^{\circ} 177$. (2006, November 10). Retrieved on 20 March 2007 from: www.crisisgroup.org/home/index.cfm?id=4497\&l=1

Countering Afghanistan's insurgency: no quick fixes, Asia Report \#123. (2006, November 2). Retrieved on 20 March 2007 from: www.crisisgroup.org/home/index. cfm?id $=4485 \& l=1$

Getting the UN into Darfur; Africa Briefing \#43. (2006, October 12). Retrieved on 20 March 2007 from: www.crisisgroup.org/home/index.cfm?id=4442\&l=1

The Arab-Israeli conflict: to reach a lasting peace, Middle East Report \#58. (2006, October 5). Retrieved on March 5 from: www.crisisgroup.org/home/index. $\mathrm{cfm} ? \mathrm{id}=4427 \& \mathrm{l}=1$

Global Leaders Call for Action on Arab-Israeli Settlement, Report. (2006, October 4). Retrieved on 5 March 2007 from: www.crisisgroup.org/home/index. $\mathrm{cfm} ? \mathrm{id}=4424 \& \mathrm{l}=1$

Securing Congo's elections: lessons from the Kinshasa showdown, Africa Briefing \#42. (2006, October 2). Retrieved on 20 March 2007 from: www.crisisgroup. org/home/index.cfm? $\mathrm{id}=4412 \& \mathrm{l}=1$

\section{European Union documents}

DG communication, European Commission (2006). Revue de Presse, 2 October 2006-29 December 2006, Brussels.

Europa, activities of the European Union: summaries of legislation. Cotonou Agreement. (2007). Retrieved on 2 September 2007 from: www.europa.eu/scadplus/leg/ en/lvb/r12101.htm

European Commission, External Relations, European Initiative for Democracy and Human Rights (n.d.). Brussels. Retrieved on 20 March 2007 from: http://ec.europa. eu/comm/external_relations/human_rights/intro/index.htm

European Commission - Delegation for the Pacific. (2007). Outcome of statement on consultations between the EU and Fiji held in Brussels from 18-19 April, Suva.

EU-Fiji talks begin in Brussels, Suva, April 18. 
Declaration by the presidency on behalf of the EU on developments in the Republic of Fiji Islands, Suva, June 22.

Economic partnership agreements: a new approach to ACP-EU trade cooperation.

Retrieved on 2 September 2007 from: www.delfji.ec.europa.eu/en/epa/

Dr Lee Duffield teaches journalism at the Queensland University of Technology and writes on news media and crisis situations globally. He is a former journalist and was an overseas correspondent with the Australian Broadcasting Corporation for more than 20 years. His research interests extend from European media and politics to communication for development in the Pacific. On leave during the past year for professional reengagement, he reported again from Europe for the $A B C$, Radio Australia and his online service EUAustralia.com. The author acknowledges the generous assistance of Andrew Stroehlein, media director of the International Crisis Group, who gave access to information kept by the organisation and provided advice in preparing this report.

I.duffield@qut.edu.au

\section{E. Massey University}

\section{Jeanz journalism education conference}

Jeanz (Journalism Education Association of NZ Inc.) is the professional body of journalism educators in New Zealand. Its aims include promoting the highest professional standards in the teaching of journalism, collecting and disseminating information about journalism education, and fostering research into journalism and journalism education.

\section{Massey University's Journalism School Wellington, December 10-11, 2007}

"The future for the mainstream: The changing demands on journalists and the challenge for journalism educators."

For more details on the conference, please go to www.jeanz.org.nz 


\begin{tabular}{|c|c|c|c|}
\hline & 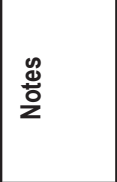 & 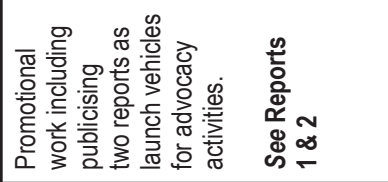 & 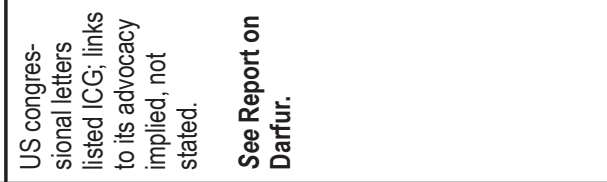 \\
\hline & 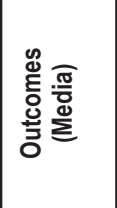 & 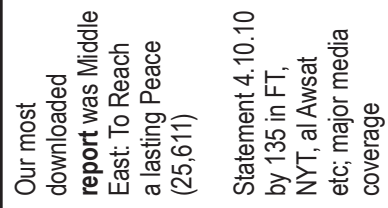 & \\
\hline & 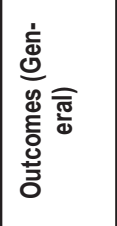 & 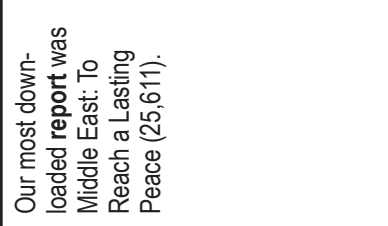 & 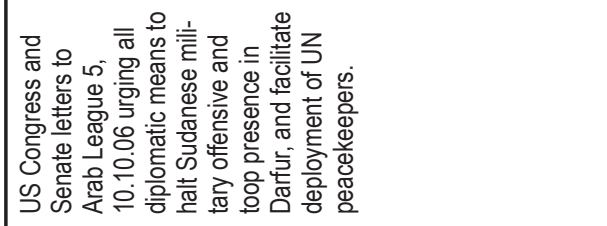 \\
\hline 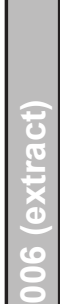 & 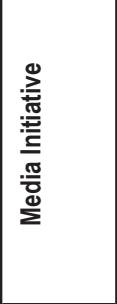 & 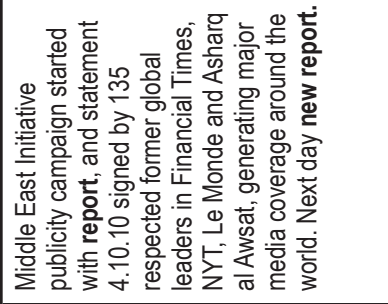 & 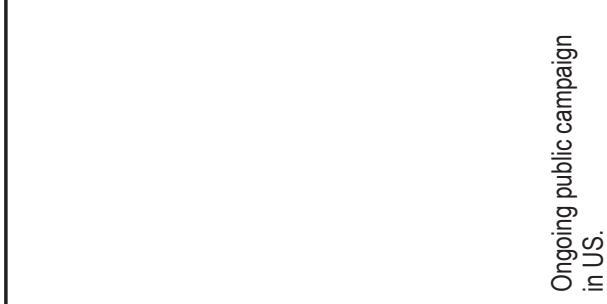 \\
\hline 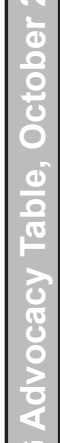 & 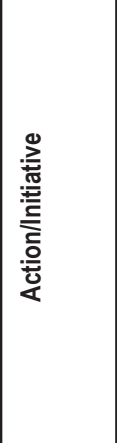 & 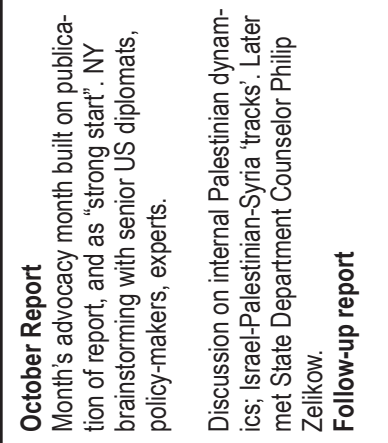 & 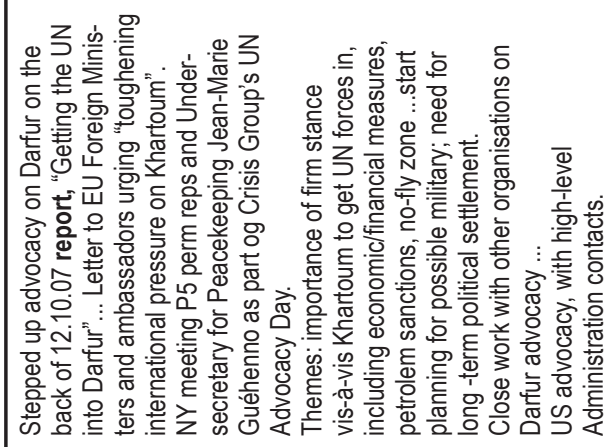 \\
\hline 0 & 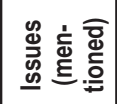 & & \\
\hline \begin{tabular}{l|}
$\frac{0}{2}$ \\
$\frac{2}{6}$ \\
$\frac{2}{2}$ \\
$\frac{2}{4}$
\end{tabular} & 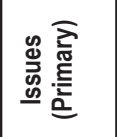 & 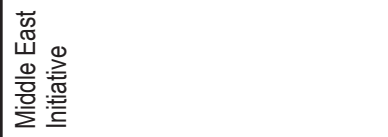 & 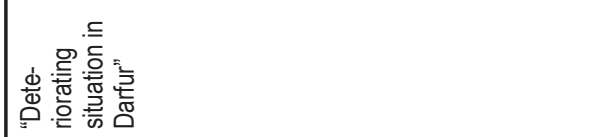 \\
\hline
\end{tabular}

